\title{
Selected Issues of Establishing and Functioning of the Transmission Easement
}

\section{Introduction}

The institution of transmission easement is regulated by the Civil Code, detailed regulations are contained in articles $305^{1}-305^{4}$. According to the provisions of the article $305^{1}$ [8] "real estate may be encumbered with a right in favor of an entrepreneur who intends to construct or which owns the facilities referred to in article 49 $\S 1$ under which the entrepreneur may use the servient estate within a designated scope, in accordance with the purpose of the facilities (transmission easement)". Legal regulation cited above specifies that the conditions of use of the property should be consistent with the intended purpose of these devices in terms necessary to ensure their proper functioning. Transmission easement is a kind of limited real right, which entitles entrepreneur to use the servient estate within a designated scope. Using this involves, among others, access to transmission facilities, the possibility of making the repair, modernization, maintenance and troubleshooting. As a result of the establishment of transmission easement, the holders of the legal title to the servient estate cannot fully exercise their rights - cannot fully collect benefits and other income of things as well cannot fully dispose of thing, which gives it art. 140 of the Civil Code [8].

Transmission easement, as a relatively new creation in Polish legislation, has characteristics of both predial servitude and personal servitude $[1,5]$. On the one hand, it can be established for the benefit of an individual or legal entity (a feature of personal servitude), on the other hand is component of the company (a feature of predial servitude).

There are two main circumstances which gave rise to the establishment of an easement: the first, when the transmission devices are already located on the property, and the second, when it is planned to build facilities. Establishing this type of the easement on the land on which devices are already built usually occurs in order to

* AGH University of Science and Technology, Faculty of Mining Surveying and Environmental Engineering, Krakow, Poland 
obtain compensation for limitations arising from the existence of devices. In the case of investments designed to establish, law protects the entrepreneur from situations in which the question of devices remains unregulated, while property owners can apply for proper compensation.

The appointment of operation of transmission easement is intended to regulate the legal relationship between property owners and transmission entrepreneurs, taking into account the public interest and the respect of property rights. A major problem studied in this work is establishing a transmission easement for perpetual usufruct and for transmission facilities not physically running through the property which is to be charged, but affecting the ownership of the property.

\section{Establishing of the Transsmision Easement}

At the beginning it is worth noting that the transmission easement can be established only to the entrepreneur and only such, who is the owner of the existing equipment, or who intends to build such devices. In particular, the owner of the devices, which bore the cost of their implementation, and does not have the status of a transmission entrepreneur, has no formal possibility of establishing a transmission easement for his own benefit.

In accordance with current legislation, there are actually four ways to establish a transmission easement. First, by agreement between the entrepreneur and the holder of the legal title to the property. Secondly, by judicial decision. Thirdly, on an administrative decision (issued by the district governor of the district). Finally, there is also the possibility of adverse possession (Fig. 1).

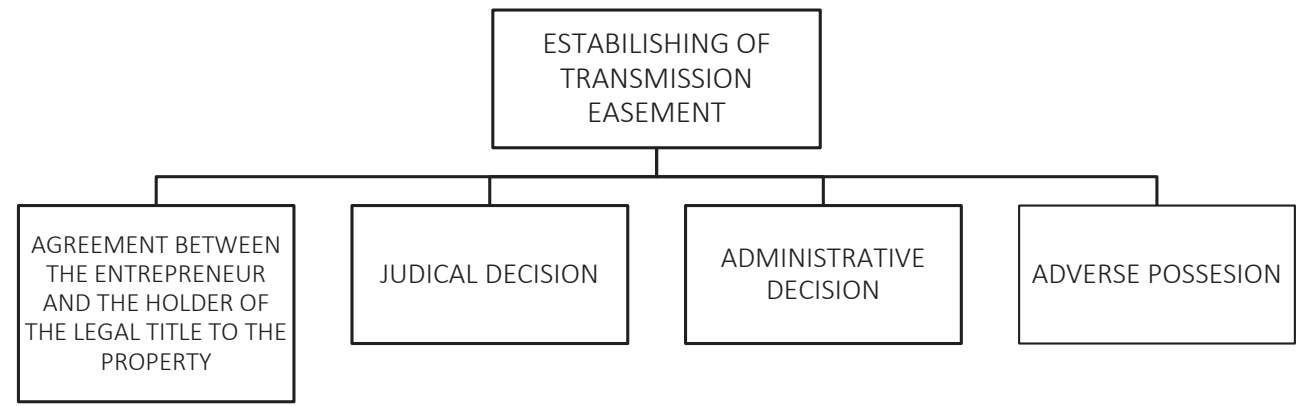

Fig. 1. Ways to establish the right of transmission easement

The Civil Code article $245 \S 1$ explicitly states that: "Subject to the exceptions provided for by the law, the provisions on ownership transfer apply accordingly to the establishment of a limited real right" [8]. Therefore, it is necessary to conclude an agreement between the parties (agreement in the form of a notarial deed). 
According to the article $305^{2}$ of the Civil Code [8], establishment of a transmission easement occurs by agreement between the property owner and the owner of the transmission device (more precisely - between the person having legal title to the property and transmission entrepreneur). Nature of the agreement implies that there is necessary consent of the two sides - on the one hand, transmission entrepreneur, on the other property owner. If the charged property is the subject of co-ownership, it requires the consent of all persons who are co-owners. According to current law, the content of the agreement establishing a transmission easement is not regulated by statute, which results in a range of flexibility in the content of any such agreement. Correctly formulated agreement should, however, contain a the description of the coverage and the course element established easements, as well as the range of activities which will be authorized to carry out the transmission entrepreneur (e.g. way directions to devices, a list of works that can be performed within the facilities erected on a specific property). The agreement should also include determination of the remuneration for the establishment of the easement, the so-called "adequate remuneration", the establishment of which is actually the subject of serious discussion between the experts in the field of property valuation $[1,5]$.

The establishment of transmission easements on the basis of agreement between the property owner and the entrepreneur is the most conciliatory form of uprising of this right. If the real estate owner refuses to execute a contract establishing the transmission easement and the easement is required for the proper operation of the facilities, the entrepreneur may demand that an easement will be established against appropriate remuneration. Similarly, if an entrepreneur refuses to execute the contract establishing the transmission easement, and the transmission easement is required for the proper operation of the facilities, the real estate owner may demand appropriate remuneration in exchange for establishment of the transmission easement. The procedure is referred to the court who establishes the contractual obligation, usually citing court experts, among others: surveyors - for the appointment of easement coverage belt and experts in the field of property valuation - for the purposes of determining the amount of remuneration for the servitude. Decision issued by the court includes the range of the exercise of the easement, along with the amount of remuneration for its establishment. Noteworthy issue is the fact that, pursuant to art. 626 [8], in cases of establishment of transmission easement, courts should apply the rules governing the procedure for the establishment of the right-of-way easement.

Another possibility for establishing a transmission easement is an administrative decision. The authority competent to issue such a decision is the governor of the district. The legal basis is article mode. 124 [9], according to which the governor, performing the task of government administration, may limit, by decision, the use of the property by granting licenses for the establishment and carrying on the property strings drainage pipes and apparatus for transmission or distribution of fluids, steam, gas and electricity and for a public communications and signaling, as well as 
other underground, above-ground or above-ground facilities and equipment necessary for the use of these cables and devices if the owner or usufructuary of real estate does not give permission to do so. This limitation shall be in accordance with the local land use plan, and in case of lack of the plan, according to the decision of establishing the location of a public investment.

Despite the relatively short period of existence of the institution of transmission easement in the Polish law system, its establishment may be by adverse possession. In this case, the entrepreneur must transfer the judicial process to demonstrate the existence of devices in real estate for 20 years (in good faith) or 30 years (in bad faith) [8].

\section{Transsmision Easement FOR Perpetual Usufruct}

The establishment of easements causes in practice to limit, to some extent, ownership of real estate. The Polish legal system contains also the right of perpetual usufruct. It is specific to the Polish civil law, individual right, relating to land property. It is classified as one of property rights, next to the ownership and limited real rights (Fig. 2).

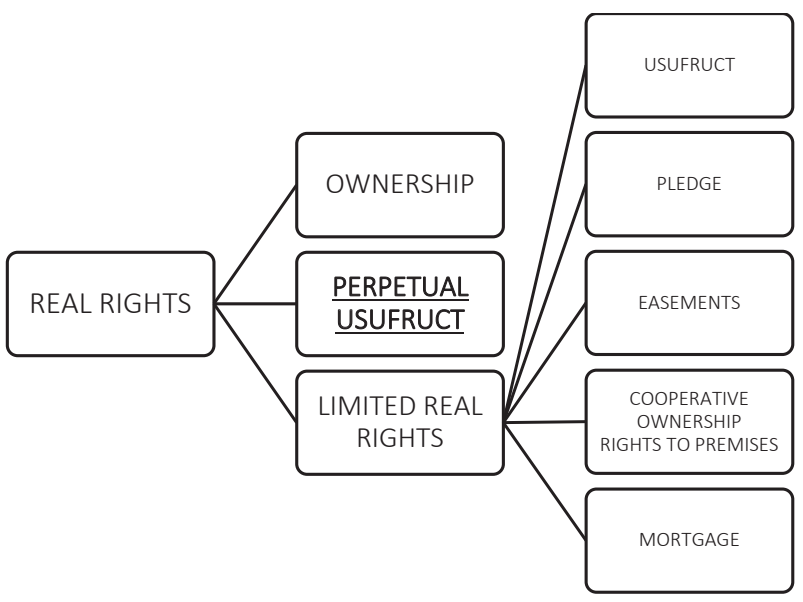

Fig. 2. Property rights by Civil Code

Source: own studies based on [8]

The right of perpetual usufruct is based on transmission for the so-called perpetual user of land which is the subject of ownership of the State Treasury, state, county, municipality or compound units in natural or legal person for a specified period - usually 99 years, particularly shorter, but not less than 40 years.

Transmission easement is established in principle on the property, which, according to the Civil Code is the kind of thing. Doubts arise in case of the need to 
establish a transmission easement on the land donated in perpetual usufruct, which is a law very similar to property rights, but its nature is not a thing, but the law. At the beginning it is worth noting that in Polish law there are clear grounds for charging on the rights of limited rights in rem, as an example, you can specify the establishment of a mortgage or pledge. It is worth noting that with the current state of the Polish law, there is no legal act which directly regulates the possibility of establishing transmission easement for perpetual usufruct. As noted in [11], the Polish government has undertaken efforts towards statutory regulation of this process in the way of changes in the Civil Code [8]. Proof of this is a bill to amend the Civil Code, published on 7th December 2011 [3].

Mentioned project provided the following change:

2) After article 285 there is added article 2851 that states as follows: Art. $285^{1}$.

$\S 1$. Easement can be established by usufructuary; it burdens the right of perpetual usufruct.

$\S 2$. Easement may be established for the perpetual usufruct.

Work on the amendment to the Civil Code [8] providing for this change was suspended, and this provision has never appeared officially in the Polish legislation, which for reasons of clarity and explicitness of worded provision, would address the issue of the establishment of transmission easement for perpetual usufruct. Finally, in connection with the fundamental shortcomings in the legislation, in order to resolve the possibility of establishing transmission easement for perpetual usufruct, the legal basis is the law of the Supreme Court and courts of general jurisdiction.

A review of case law in this respect shows that the most widely corresponding permissive with the present issue rulings are: the decision of the Supreme Court on Ref. Act III CSK 174/13 from 28 March 2014. [7], and in some sense opposite to that the decision of the Supreme Court on Ref. Act III CZP 5/15 of 22 April 2015 [6].

In giving the first of these provisions, the Supreme Court referred to article $305^{1}$ and 285 of the Civil Code [8], which it records in its essence, allowing to encumber real estate as a thing. It has been assessed that encumbering the law should be the exception, and there is no reason to extend it to the transmission easement, which, due to its nature (mission of providing media population, the need to build adequate infrastructure), requires a stable and sustainable over time legal title, which guarantees only the right of ownership. The argument raised by the judges was the fact that the easement expires upon the expiration of the right of perpetual usufruct. As indicated in [11], case law established by the aforesaid provision was very willingly used by different courts, which consistently blocked the establishment of transmission easements based on the above reasons.

At the same time, with subsequent rulings that prevent users perpetual obtain compensation on the basis of location of transmission equipment, there were increasing doubts, which resulted in asking to the Supreme Court. The Supreme Court on 22 April 2015 issued a decision in case Ref. Act III CZP 5/15 [6]. On its pages, the Supreme Court formally confirmed the possibility of establishing an easement, 
including transmission easement for perpetual usufruct, and for the perpetual usufructuary. The judges in the grounds of the provisions appealed to an earlier decision in a case of Ref. Act III CSK 174/13 denouncing misread the meaning of this provision. The court referred in the negative to establish a transmission easement for perpetual usufruct only if at the same time it could be charged with the property itself (understood as a thing) (Tab. 1). It was concluded that the easement can charge not only a plot of land (understood as a thing), but also the perpetual usufruct of land, and that the easement may be established for the perpetual usufructuary.

Despite the fundamental differences between the easement and the transmission easement, the position of the Supreme Court can be extended for transmission easement.

Table 1. Comparison of case law on the transmission easement for perpetual usufruct

\begin{tabular}{||c|c|c||}
\hline Decision & Ref. act III CSK 174/13 & Ref. act III CZP 5/15 \\
\hline \hline \multirow{6}{*}{ Key findings } & $\begin{array}{c}\text { it is possible to encumber real estate } \\
\text { (other law) as things } \\
\text { encumbering the legal regulation } \\
\text { should be an exceptional situation } \\
\text { right of perpetual usufruct is not } \\
\text { enough stable and permanent for } \\
\text { transmission easement }\end{array}$ & $\begin{array}{l}- \text { establishing a transmission easement } \\
\text { for perpetual usufruct and to the } \\
\text { perpetual user is possible } \\
\text { transmission easement for perpetual } \\
\text { usufruct should not be only when } \\
\text { at the same time it could be charged } \\
\text { with the property itself (understood } \\
\text { as a thing) }\end{array}$ \\
\hline
\end{tabular}

Finally, as noted in [11] situation in which the usufructuary is deprived of the possibility of establishing transmission easement would be situations in which the prohibition on the establishment of such an easement will be result directly from a perpetual usufruct agreement. Otherwise there is no reason to withdraw from formal procedure for charging for use of perpetual easement transmission.

\section{Transmission Easement on the Property, Which Is Not Directly Charged by the Transmission Devices}

Rarely discussed, but very important problem is establishing a transmission easement for devices not physically running through the property, which is to be charged, but only affecting ownership. The case law indicates that in this case there is no basis to establish the transmission easement. In practice, placing the transmission equipment on a nearby estate causes significant restrictions on the exercise of property rights, for which, in the case of not establishing transmission easement, the owner does not receive due compensation.

The situation described above may have at least two cases. First, when the transmission devices are located on the property nearby, but the extent of their impact exceeds the boundaries of the property on which they are located and ascends the 
property situated in the neighborhood. Secondly, when the location of transmission equipment forces indirect burden on neighboring property, which is necessary to obtain access to a public road.

The first of these situations is especially for high-voltage power lines, the impact of which often goes far beyond the location of devices. Widths of transmission easements are often the greatest just for power lines of high voltage. To introduce the concept of an easement area, it is necessary to define the concept of the zone of transmission easements. According to article $305^{2}$ of the Civil Code [8] area of transmission easement should be defined so as to be "required for the proper operation of the facilities". Easement areas mainly depend on the width of the strip of land necessary for the proper operation of the network and operation of transmission facilities. This zone is most commonly called the operational zone or technological zone (Fig. 3), and its parameters should be defined by the network operator.

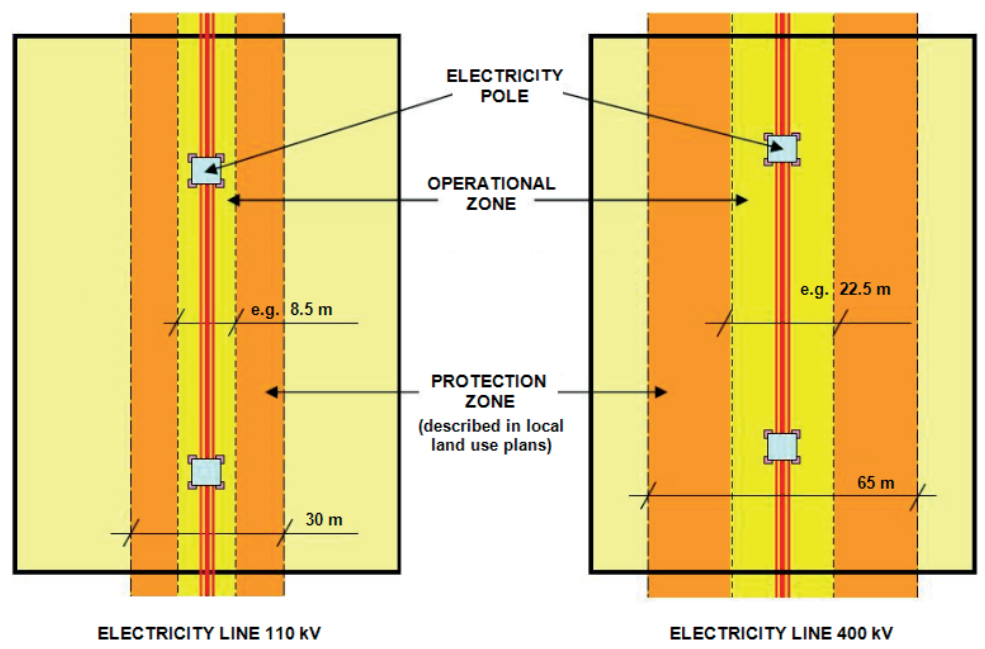

Fig. 3. Technical parameters of the transmission line and the width of transmission easement zones

Source: http://www.sluzebnosc-przesylu.pl/sluzebnosc-przesylu

Moreover, there can be established additional zones, in order to protect the surrounding areas against the effects of transmission equipment. These zones, called for example protection zones, are given frequently in studies of planning, mainly local land use plans. Their width depends among others the technical parameters of the network, as well as other factors individually analyzed, could be many times the width of the operational (technological) zone.

In practice, the width of the transmission easement zone is often identified with the area of direct influence of the transmission line. This approach seems to be incorrect, especially in the context of the previously cited article $305^{2}$ of the Civil 
Code [8], which clearly indicated the criterion of "the proper operation of the facilities". It seems that the work of restoration or the need to remove any failures may be associated even with the need to bring heavy equipment. For such purposes the area of operational zone often turns out to be too narrow. A preferred would be a situation in which the transmission easement would be identified with the protection zone together with operational zone, which sets the owner of the device - the transmission entrepreneur, as the entity responsible for the proper functioning of the infrastructure. In some cases, the owner of transmission facilities should ensure a periodic access to infrastructure facilities, which it seems, should take into account transmission easement.

Due to the fact that the reach of transmission equipment may extend beyond the area of real estate, which includes the equipment, the establishment of transmission easement may also affect adjacent properties. The following are examples showing the essence of the problem analyzed (Figs 4, 5).

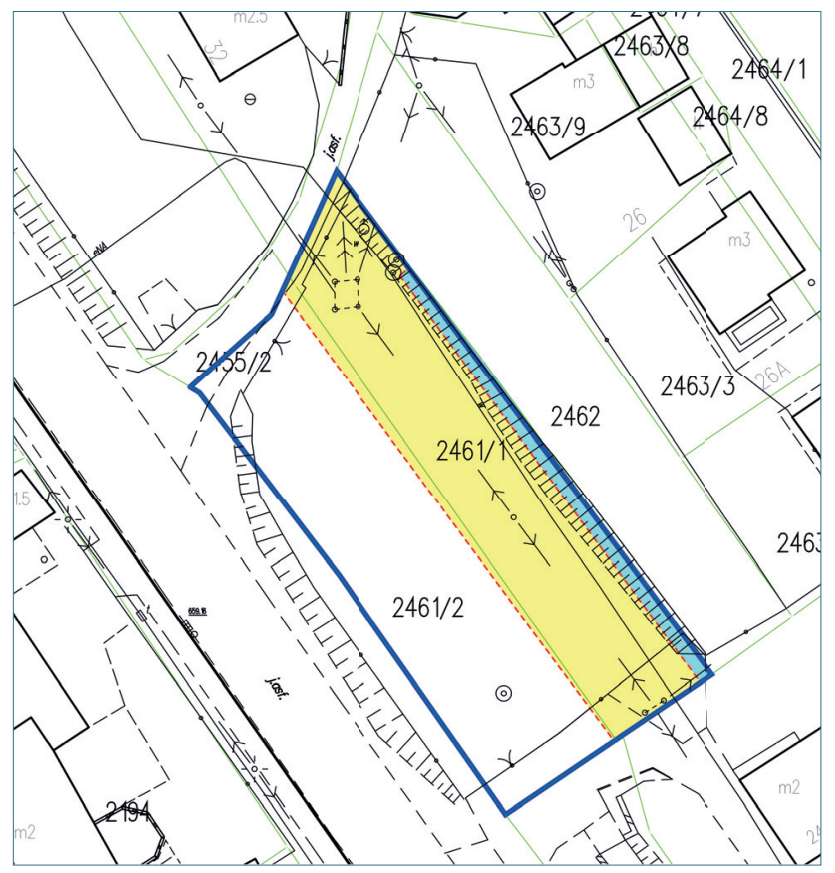

Fig. 4. Site map of the city of Nowy Targ (fragment) Source: [2]

The figure above shows a real estate property, consisting of parcels number 2461/1 of the area 0.0612 hectares and 2461/2 with the area 0.0671 hectares (total area of land is 0.1283 hectares). Through the area of the property runs an overhead power line with a voltage of $11 \mathrm{kV}$. Transmission easement zone is identified for this 
property as a protection zone with a width of 5 meters from the extreme wires. In this way, the surface area of transmission easement is about 0.0580 hectares $(45 \%$ of the entire property, almost all of the plot 2461/1). In Figure 4, the easement zone is marked in yellow, and blue means a part of the plot 2461/1 of the area 0.0073 hectares, which is not covered by the easement, and virtually excluded from use. The whole area of the plot 2461/1 has become useless. The problem is, however, another aspect. In the present case, the designated zone easement does not correspond to the actual limitation in the use of the property. Access of technical services to the devices cannot be done along the easement zone (protection zone). The property is fenced and the entrance to the plot is carried out through two gates located on plot number 2461/2. Therefore, the optimal solution would be to establish a transmission easement on the plot number $2461 / 2$, in which it would be possible the existence of the access road to the power poles, especially that in the northern part of the plot 2461/1 there is a transformer, which repairs require using a boom.

The second situation concerns the developed land - plot number 2913/1, as well as undeveloped plot number 2913/2. Through the plot number 2913/2 runs energy line of medium voltage (running approximately transverse to the boundary lines of the front of the plot). What is important - energy line runs surrounded by dense vegetation high, and therefore relatively often is carried out conservation work (removal of broken branches from power lines, trimming the tree crowns, etc.). Transmission easement is established on the plot number 2913/2.

a)

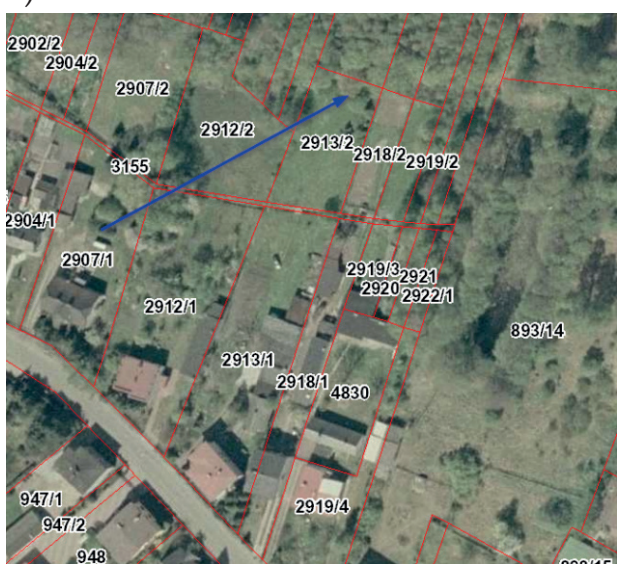

b)

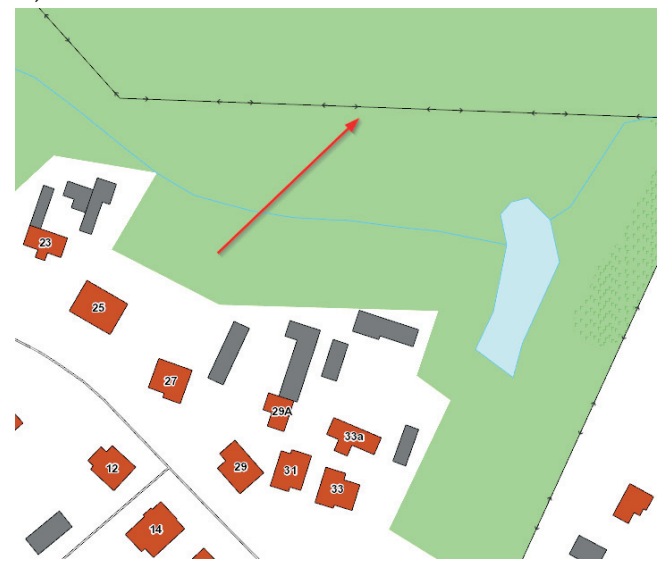

Fig. 5. Parcels number 2913/1, 2913/2 - the problem with the establishment of transmission easement

Source: http://geoportal.gov.pl

The plot 2913/2 has no legally regulated access to a public road, access is done through an adjacent plot No. 2913/1 (separated from the plot 2913/1 across the ditch cadastral parcel number 3155), which is the subject of property rights of the owner of 
the plot 2913/2. For the maintenance of power lines, each time heavy equipment enters the plot number 2913/1, resulting in, among others, destruction of greenery and nuisance for the owner. There is no doubt that the situation described above results in charging property consisting of plot 2913/1. The entrepreneur should also establish a transmission easement through parcel 2913/1, involving the release of land plot for the purposes of access to technical infrastructure. This confirms the case law of the District Court in O. I Civil Division. The substantiation of decision from 23 May 2014, rejecting the application for the establishment of transmission easement, it states the possibility of establishing transmission easement for the transmission passing through the property unencumbered by any devices. In this case, it should be established transmission easement, not the land easement. The dominant thing is transmission device, or a company, not the adjoining property.

It is visible that a large role in influencing of transmission easement on adjacent properties plays planning policy. Municipality through rational spatial planning can minimize adverse events associated with the transmission easement, such as the exclusion of part of the property of the building [4]. The relation of local spatial management plans for transmission facilities may be twofold: firstly, the plan specifies the courses of the planned zones (the formation of a new state planning), and secondly, the projected plan takes into account the presence of existing equipment (optimization of the existing state of development). The following are the opposite examples of rational and less pragmatic approaches to destination sites in the area of location of transmission facilities.

a)



b)

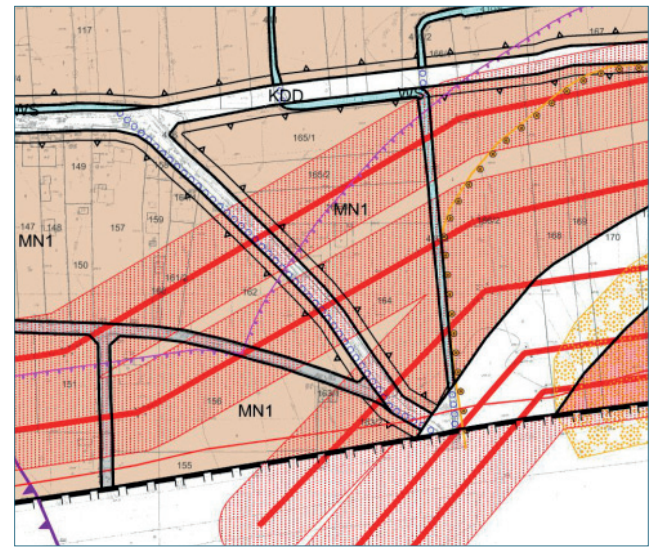

Fig. 6. Transmission facilities and local zoning plans

Source: [4]

Example on the left side (Fig. 6a) illustrates the rational approach to transmission facilities. The figure specified technical area around the municipal district heating lines [10]. Because of the existence of the line of heating, its immediate surroundings 
were excluded from residential development, and allocated to the green areas. Residential areas were concentrated in other parts of the plan, resulting in the lack of serious restrictions on the location of buildings. Example positioned on the right shows part of the drawing, which are visible areas designated for residential single families. However, due to numerous power lines of high and medium voltage, the vast majority of visible plots and so will not be able to be used in accordance with the intended purpose.

\section{Summary}

Transmission easement is currently the most widely used legal form that allows for transmission entrepreneurs to use of someone else's property. Meanwhile, with the increasing number of new easements, reveal other legal and technical problems, related to their lawmaking and functioning.

A very important issue is the possibility of setting up transmission easement for perpetual usufruct and for the perpetual user. This issue is not currently regulated by law, there are also no legislative experiences from abroad as the perpetual usufruct right is characteristic of the Polish legal system. In addition, unstable and at times contradictory position of the Supreme Court and courts of general jurisdiction indicate the complexity of the issue. This gives a basis for further research on interoperability of transmission easement and right of perpetual usufruct.

The primary objective of the transmission easement is to provide access to the transmitted media for certain properties. Better equipment significantly affects the increase in the value of such property. At the same time established easement results in a significant reduction in functionality, and going further - the value of the property encumbered and is in the range of negative impacts of the transmission device, but without formally established easement. As part of this study were presented practical cases of the impact of transmission facilities on the property adjacent, not covered by the transmission easement. Study on even such a small number attempt leads to the conclusion, that the scope of the impact of transmission easement frequently extend beyond formally designated easement zones, what should be taken into account with the correct construction of contracts establishing this right, as well as many other aspects of real estate management, in particular in the zone planning.

\section{References}

[1] Balawejder M., Busko M., Cellmer R., Juchniewicz-Piotrowska K., Leń P., Mika M., Szczepankowska K., Wójciak E., Wójcik-Leń J., Źróbek S.: Aktualne problemy gospodarki nieruchomościami na tle przemian organizacyjno-prawnych. Wyższa Szkoła Inżynieryjno-Ekonomiczna, Rzeszów 2015. 
[2] Bochaczyk J.: Służebność przesyłu jako szczególny przypadek ograniczenia praw do nieruchomości. AGH, Kraków 2015 [M.Sc. thesis].

[3] Druk nr 74 - Pismo Prezesa Rady Ministrów z dnia 7 grudnia 2011 r. projekt ustawy o zmianie ustawy - Kodeks cywilny.

[4] http://planowanie.um.krakow.pl/.

[5] Lewandowski P.: Stużebność przesyłu w prawie polskim. Wolters Kluwer Polska, 2014.

[6] Postanowienie Sądu Najwyższego z dnia 22 kwietnia 2015 r. Sygn. akt III CZP 5/15.

[7] Postanowienie Sądu Najwyższego z dnia 28 marca 2014 r. Sygn. akt III CSK 173/13.

[8] Ustawa z dnia 21 sierpnia 1997 r. o gospodarce nieruchomościami. Dz.U. 1997, nr 115, poz. 741 z późniejszymi zmianami, tekst jednolity: Dz.U. 2015, poz. 1774 [Journal of Laws 1997, no. 115, item 741 with amendments, consolidated text: Journal of Laws 2015, item 1774].

[9] Ustawa z dnia 23 kwietnia 1964 r. Kodeks cywilny. Dz.U. 1964, nr 16, poz. 93 z późniejszymi zmianami, tekst jednolity: Dz.U. 2014 z późniejszymi zmianami [Journal of Laws 1964, no. 16, item 93 with amendments, consolidated text: Journal of Laws 2014 with amendments].

[10] Ustawa z dnia 27 marca 2003 r. o planowaniu i zagospodarowaniu przestrzennym. Dz.U 2003, nr 80, poz. 717 z późniejszymi zmianami [Journal of Laws 2003, no. 80 , item 717 with amendments].

[11] Zamroch P.: Problematyka prawna urzadzeń przesyłowych na tle orzecznictwa Sądu Najwyższego i sądów powszechnych. [in]: Dąbek J., Nowakowska M., Zamroch P., Wybrane zagadnienia wyceny nieruchomości a problematyka prawna, ekonomiczna i przestrzenna zwiazana z infrastruktura techniczna, wyd. 2 poprawione, Polska Federacja Stowarzyszeń Rzeczoznawców Majątkowych, Warszawa 2015. 